\title{
Chocolate Milk Sweetened With Stevia: Acceptance by Children
}

\section{Verruma-Bernardi $\mathrm{MR}^{1}$, Lee $\mathrm{K}^{2}$, Palchak $\mathrm{T}^{3}$ and Bordi $\mathrm{PL}^{{ }^{*}}$}

${ }^{1}$ Center for Agrarian Sciences, Federal University of São Carlos, CNPq/Brazil

${ }^{2}$ Department of Retail, Hospitality, and Tourism Management, University of Tennessee, Knoxville

${ }^{3}$ Berkey Creamery, The Pennsylvania State University

${ }^{4}$ Center for Food Innovation, School of Hospitality Management, Pennsylvania State University

${ }^{*}$ Corresponding author: Bordi PL, Center for Food Innovation, School of Hospitality Management, Pennsylvania State University, USA, E-mail: plbjr@psu.edu

Citation: Verruma-Bernardi MR, Lee K, Palchak T, Bordi PL (2015) Chocolate Milk Sweetened With Stevia: Acceptance by Children. J Obes Overweig 1(1): 103. doi: 10.15744/2455-7633.1.103

Received Date: January 19, 2015 Accepted Date: May 21, 2015 Published Date: May 27, 2015

\section{Abstract}

We investigated children's acceptance of chocolate non-fat milk, sweetened with sucrose and stevia (Enliten ${ }^{\circ}$ ) with eighty-four children (11-14 years old) under four sweetness conditions. Samples were evaluated with a structured 7-point hedonic scale, ranging from "super bad" to "super good", for color, sweetness, flavor, texture and overall liking. The chocolate milk with $18 \mathrm{~g}$ of sucrose with stevia was more accepted; chocolate milk with no sugar added (NSA) and with stevia had lower notes.

Keywords: Chocolate Milk; Stevia; Color; Flavor; Preference; Sweetness

\section{Introduction}

Milk contributes substantially to nutrient intake. Those who consumed milk had higher intakes of several key nutrients. Milk provides more than 50 percent of the daily intake of vitamin $\mathrm{D}$, over 30 percent of calcium, and over 20 percent of vitamin A, riboflavin, vitamin $\mathrm{B}_{12}$, and phosphorus for milk [1].

According to the 2010 USDA Dietary Guidelines for Americans a nutritious choice - unlike many soft drinks and fruit juices, flavored milk provides at least 8 grams of protein per serving and essential nutrients such as calcium, vitamin $A, D, B_{12}$, potassium, phosphorous, riboflavin, and niacin. This unique nutrient profile along with small amounts of sugar added to nutrient-dense foods, such as reduced fat milk products, may encourage intake of such products by improving their palatability, fostering increased nutrient intake without excessive calories [2].

Due to these benefits, all Americans 9 and older are encouraged to consume three cups of fat-free or low fat fluid milk or equivalent milk products per day. The Institute of Medicine (2010) recommended children aged between 9-13 years consume 1,300 mg of calcium per day [3]. Sebastian (2010) said that young children (age 2-11 years) consumed significantly more milk than teens or adults; milk therefore provided a higher proportion of their total nutrient intake [1].

Chan et al. (1995) related that young girls whose dietary calcium intake was provided primarily by dairy products at or above the recommended dietary allowances had an increased rate of bone mineralization. Increased intake of dairy foods did not increase overall total or saturated fat intake and was not associated with excessive weight gain or increased body fat $[4,5]$.

The overconsumption of added sugar by kids is debated by everyone from parents to policymakers around the world [6]. Conners and Bednar (2002) related that child nutrition programs are well positioned to promote its consumption and thus have a salutary effect on the nutritional status of school children [7].

Murphy et al. (2008) described that consumption of either flavored or plain milk is associated with a positive influence on nutrient intakes by children in the United States and According to Johnson et al. (2002), children who consume flavored milk have higher calcium intakes, but similar total fat and added sugar intakes as children who do not drink flavored milk. Boor (2001) described that chocolate is the most popular milk flavor and represents a popular option among children and adults [8-10].

Fayeta et al. (2013) related that children and adolescents evaluating the effects of flavored milk on improving total milk and nutrient intake along with important clinical end points such as bone health and body composition are recommended [11].

Tachdjian et al. (2013) related that sugar and calories are key components that can be limited to render a positive nutritional effect on health. High-intensity sweeteners can provide the sweetness of sugar, with various taste qualities. Because they are many times sweeter than sugar, much less of the sweetener is required to replace the sugar [12]. 
Approximately $16 \%$ of children and adolescents' total caloric intakes came from added sugars [13]. Blackburn et al. (1997) indicated that flavored milk with artificial sweetener provides the desired sweetness and palatability without contributing to caloric intake [14].

Stevia rebaudiana (Bert.) Bertoni a herbaceous perennial plant native to subtropical and tropical rainforests of South America is an all-natural zero-calorie sweetener [15] used in a wide variety of food and beverages [16]. Stevia seems well-positioned to become a major high-potency sweetener [17] for the growing natural food market, especially given its lack of undesirable taste characteristics [18].

\section{Materials and Methods}

\section{Milks}

Treatments comprised four types of chocolate milk produced by Ingredion Incorporated ${ }^{\mathrm{Tw}}$. The ingredients and nutritional information of chocolate milk samples are described in Table 1. Three samples contained high-intensity Enliten ${ }^{\oplus}$, a naturally lowcalorie sweetener obtained from Stevia rebaudiana; the remaining sample was sweetened with $28 \mathrm{~g}$ of sucrose.

\begin{tabular}{|c|c|c|c|c|}
\hline & \multicolumn{4}{|c|}{ Chocolate milk } \\
\hline & $\begin{array}{l}\text { Stevia and sucrose } \\
(20 \mathrm{~g})(\mathrm{A})\end{array}$ & $\begin{array}{l}\text { Stevia and sucrose } \\
(18 \mathrm{~g})(\mathrm{B})\end{array}$ & $\begin{array}{c}\text { NSA }^{* *} \text { with Stevia } \\
\text { (C) }\end{array}$ & $\begin{array}{c}\text { Control - with } \\
\text { sucrose (28g) (D) }\end{array}$ \\
\hline $\begin{array}{c}\text { Enliten }^{\oplus} \text { Reb A Stevia } \\
\text { Sweetener (\%) }\end{array}$ & 0.015 & 0.015 & 0.0247 & 0 \\
\hline Calories $^{*}$ & 120 & 110 & 90 & 150 \\
\hline Protein $(\mathrm{g})^{*}$ & 8 & 8 & 8 & 8 \\
\hline Calcium $(\mathrm{g})^{*}$ & 300 & 300 & 300 & 300 \\
\hline Total fat $(\mathrm{g})^{*}$ & 0.5 & 0.5 & 0.5 & 0.5 \\
\hline
\end{tabular}

NSA = non-sugar-added

The Daily Value, the recommended daily intake of a nutrient, for calcium is $1,000 \mathrm{mg}$

Table 1: Nutritional information of four chocolate milks - per serving $238 \mathrm{~mL}$

\section{Sensory test}

Eighty-four students were recruited at random to take part in the study. Panels were female $(\mathrm{n}=48)$ and male $(\mathrm{n}=36)$, aged from 12 to 14 years (Table 2). For sensory evaluation, chocolate milk samples were removed from the refrigerator, placed in 2 ounce white cups coded with random 3-digit numbers and brought to $5{ }^{\circ} \mathrm{C}$. Tasters were instructed to evaluate the chocolate milk with respect to color, flavor, sweetness, texture/feel and overall liking. Samples were rated on a 7-point hedonic scale, ranging from 1 ("super bad") to 7 ("super good"). Between samples, the participants ate a cream cracker biscuit and drank water. The first-order and carry-over effects were balanced using a design based on [19]. Samples were presented monadically.

Panelists were asked about: liking white milk (yes or no); liking chocolate milk (yes or no); frequency of milk consumption at lunch during the week, and choice of drink for school lunch (white milk, chocolate milk, both, or neither). Compusense Five (Compusense $^{\varpi}$ ), software was used to perform the sensory analysis. Analysis of variance (ANOVA) was used to compare mean scores of each chocolate milk [20]. This study was approved by the Institutional Review Board at a large Northeastern University.

\begin{tabular}{|c|c|c|c|}
\hline & \multicolumn{3}{|c|}{ Age n (\%) } \\
\hline Gender & 12 & 13 & 14 \\
\hline Male & $7(8.3)$ & $26(31.0)$ & $3(3.6)$ \\
\hline Female & $12(14.3)$ & $32(38.1)$ & $4(4.8)$ \\
\hline & $19(22.6 \%)$ & $58(69.1 \%)$ & $7(8.3 \%)$ \\
\hline
\end{tabular}

Table 2: Characteristics of children panels

\section{Materials and Methods}

The majority of tasters liked both white and chocolate milk:

\begin{tabular}{|c|c|c|}
\hline Answers & White milk \% (n) & Chocolate milk \% (n) \\
\hline Yes & $85.7(72)$ & $92.9(78)$ \\
\hline No & $14.3(12)$ & $7.1(6)$ \\
\hline
\end{tabular}

$\mathrm{n}=84$

Table 3: Liking rate for white and chocolate milk

Children's milk consumption frequency during lunch (Table 4) showed that $47.6 \%$ had milk 4 or more times per week; $23.8 \%$ had milk 3 times a week; while 14\% did not consume milk. 


\begin{tabular}{|c|c|}
\hline Weekly school lunch milk consumption (servings) & $\mathbf{n}(\%)$ \\
\hline 0 & $13(14.0)$ \\
\hline 1 & $4(4.8)$ \\
\hline 2 & $4(4.8)$ \\
\hline 3 & $20(23.8)$ \\
\hline$\geq 4$ & $40(47.6)$ \\
\hline
\end{tabular}

$\mathrm{n}=84$

Table 4: Consumption frequency children of milk for school lunch during the week

\begin{tabular}{|c|c|}
\hline Choice & Answers n (\%) \\
\hline White milk & $6(7.1)$ \\
\hline Chocolate milk & $53(63.1)$ \\
\hline Both the same & $20(23.8)$ \\
\hline Neither & $6(7.1)$ \\
\hline
\end{tabular}

$\mathrm{n}=84$

Table 5: School lunch milk type preference

Table 6 gives sensory preference (color, flavor, sweetness, texture, overall liking) for the four chocolate milks. Color of chocolate milk sample containing sucrose and stevia - $18 \mathrm{~g}(\mathrm{~B})$ and $20 \mathrm{~g}(\mathrm{~A})$ received $100 \%$ approval [21].

For sweetness, flavor and texture there was no significant difference ( $\mathrm{p} \geq 0.05)$, among the samples. The chocolate milk with $18 \mathrm{~g}$ of sucrose with stevia was more accepted and sample with NSA and with stevia (C) had lower notes [22-25]. Panelists significantly prefer chocolate milk with $18 \mathrm{~g}$ sucrose and stevia.

\begin{tabular}{|c|c|c|c|c|}
\hline \multirow[b]{2}{*}{ Liking } & \multicolumn{4}{|c|}{ Chocolate milk } \\
\hline & with stevia and sucrose $-20 \mathrm{~g}(\mathrm{~A})$ & with stevia and sucrose- $18 \mathrm{~g}$ (B) & NSA with stevia (C) & with sucrose- $28 \mathrm{~g}(\mathrm{D})$ \\
\hline & \multicolumn{4}{|c|}{ Color } \\
\hline Means $^{1}$ & $6.02^{\mathrm{ab}}$ & $6.18^{\mathrm{a}}$ & $5.65^{\mathrm{c}}$ & $5.94^{\mathrm{b}}$ \\
\hline Approval $(\%)^{2}$ & 100 & 100 & 89.29 & 96.43 \\
\hline Indifferent $(\%)^{3}$ & 0 & 0 & 9.52 & 2.38 \\
\hline \multirow[t]{2}{*}{ Rejection $(\%)^{4}$} & 0 & 0 & 1.19 & 1.19 \\
\hline & \multicolumn{4}{|c|}{ Sweetness } \\
\hline Notes $^{1}$ & $5.96^{\mathrm{b}}$ & $6.24^{\mathrm{a}}$ & $4.69^{c}$ & $5.85^{\mathrm{b}}$ \\
\hline Approval (\%) ${ }^{2}$ & 92.86 & 94.05 & 54.76 & 91.67 \\
\hline Indifferent $(\%)^{3}$ & 4.76 & 3.57 & 25.00 & 3.57 \\
\hline \multirow[t]{2}{*}{ Rejection $(\%)^{4}$} & 2.38 & 2.38 & 20.24 & 4.76 \\
\hline & \multicolumn{4}{|c|}{ Flavor } \\
\hline Notes $^{1}$ & $5.90^{\mathrm{b}}$ & $6.29^{\mathrm{a}}$ & $4.86^{\mathrm{c}}$ & $6.06^{\mathrm{b}}$ \\
\hline Approval (\%) ${ }^{2}$ & 100 & 96.43 & 55.95 & 2.38 \\
\hline Indifferent $(\%)^{3}$ & 0 & 1.19 & 29.76 & 8.33 \\
\hline \multirow[t]{2}{*}{ Rejection $(\%)^{4}$} & 0 & 2.38 & 14.29 & 89.29 \\
\hline & \multicolumn{4}{|c|}{ Texture } \\
\hline Notes $^{1}$ & $5.74^{\mathrm{b}}$ & $6.14^{\mathrm{a}}$ & $5.18^{\mathrm{c}}$ & $5.75^{\mathrm{b}}$ \\
\hline Approval (\%) ${ }^{2}$ & 90.48 & 96.43 & 80.95 & 89.29 \\
\hline Indifferent $(\%)^{3}$ & 5.95 & 3.57 & 7.34 & 7.14 \\
\hline \multirow[t]{2}{*}{ Rejection $(\%)^{4}$} & 3.57 & 0 & 10.71 & 3.57 \\
\hline & \multicolumn{4}{|c|}{ Overall liking } \\
\hline Notes $^{1}$ & $6.06^{\mathrm{b}}$ & $6.38^{\mathrm{a}}$ & $5.02^{\mathrm{d}}$ & $5.93^{\mathrm{c}}$ \\
\hline Approval (\%) ${ }^{2}$ & 97.62 & 98.81 & 67.86 & 91.67 \\
\hline Indifferent $(\%)^{3}$ & 2.38 & 0 & 22.62 & 3.57 \\
\hline Rejection $(\%)^{4}$ & 0 & 1.19 & 9.52 & 4.76 \\
\hline
\end{tabular}

Means in the same row followed by the same superscript do not differ statistically at $5 \%$ Tukey

${ }^{1}$ Scale: $1=$ super bad, $2=$ really bad, $3=$ bad, $4=$ maybe good or bad, $5=$ good, $6=$ really good, $7=$ super good;

${ }^{2}$ Notes for approval $=5,6,7 ;{ }^{3}$ Notes for indifferent $=4 ;{ }^{4}$ Notes for rejection $=1,2,3$

Table 6: Preference test of the chocolate milk for color, sweetness, flavor, texture and overall liking 


\section{Conclusion}

The use of stevia and small amounts of sucrose increased taste acceptance of chocolate milk with school age children. Using stevia saved 40 calories per serving. Chocolate milk which used stevia alone was least preferred by the panel. A future study might look at optimizing sucrose levels to increase acceptance while minimizing added calories.

\section{Acknowledgement}

This study was funded by Ingredion Corporate ${ }^{\mathrm{TM}}$, however, analysis and final results of this study were not influenced by representatives of the company. Sensory software was funded by a grant from Compusense Five.

\section{References}

1. Sebastian RS, Goldman JD, Wilkinson EC, LaComb RP (2010) Fluid milk consumption in the United States: What we eat in America, NHANES 2005-2006. Food Surveys Research Group Dietary Data Brief.

2. Report Dietary Guidelines For Americans (2010) U.S. Department of Agriculture and U.S. Department of Health and Human Services.

3. Committee to Review Dietary Reference Intakes for Vitamin D and Calcium, Food and Nutrition Board, Institute of Medicine (2010) Dietary Reference Intakes for Calcium and Vitamin D. Washington, DC: National Academy Press.

4. Chan GM, Hoffman K, McMurry M (1995) Effects of dairy products on bone and body composition in pubertal girls. J Pediatr 126: 551-6.

5. Dairy foods (2003) Dairy foods for today's pre-teens. Tools for innovation. Dairy Manag 1: 1-5.

6. Ayoob K (2013) Sugar intake and our kids: The not-so-sweet news for the US. 2013. Global Stevia Institute.

7. Conners P, Bednar C (2002) Promoting a calcium initiative in school cafeterias. J Child Nutr Manag 26.

8. Murphy MM, Douglass JS, Johnson RK, Spence LA (2008) Drinking flavored or plain milk is positively associated with nutrient intake and is not associated with adverse effects on weight status in US children and adolescents. J Am Diet Assoc 108: 631-9.

9. Johnson RK, Frary C, Wang MQ (2002) The nutritional consequences of flavored-milk consumption by school-aged children and adolescents in the United States. J Am Diet Assoc 102: 853-6.

10. Boor KJ (2001) Fluid dairy product quality and safety: looking to the future. J Dairy Sci 84: 1-11.

11. Fayeta F, Ridgesb LA, Wrightb JK, Petoczc P (2013) Australian children who drink milk (plain or flavored) have higher milk and micronutrient intakes but similar body mass index to those who do not drink milk. Nut Res 33: 95-102.

12. Tachdjian C, Tang XQ, Karanewsky DS, Servant G, Li X, et al. (2013) Sweet flavor modifier. Patent 20130041046.

13. McGuire S (2012) Ervin RB, Kit BK, Carroll MD, Ogden CL. Consumption of added sugar among U.S. children and adolescents, 2005-2008. NCHS Data Brief no 87. Hyattsville, MD: National Center for Health Statistics. Adv Nutr 3: 534.

14. Blackburn GL, Kanders BS, Lavin PT, Keller SD, Whatley J (1997) The effect of aspartame as part of a multidisciplinary weight-control program on short-and long-term control of body weight. Am J Clin Nutr 65: 409-18.

15. Jackson AU, Tata A, Wu C, Perry RH, Haas G, et al. (2009) Direct analysis of Stevia leaves for diterpene glycosides by desorption electrospray ionization mass spectrometry. Analyst 134: 867-74.

16. Ahmed MB, Salahin M, Karim R, Razvy MA, Hannan, et al. (2007) An efficient method for in vitro clonal propagation of a newly introduced sweetener plant (Stevia rebaudiana Bertoni.) in Bangladesh. A.E.J.S.R 2: 121-5.

17. Fry JC, Yurttas N, Biermann KL (2011) Sweetness concentration-response behavior of rebiana at room and refrigerator temperatures. J Food Sci 76: S545-8.

18. Prakash I, DuBois GE, Clos JF, Wilkens KL, Fosdick LE (2008) Development of rebiana, a natural, non-caloric sweetener. Food Chem 46: S75-82.

19. Macfie HJH, Bratchell N, Grenhoff K, Vallis LV (1989) Designs to balance the effect of order of presentation and first-order carry-over effects in hall tests. J Sens Stud 4: 129-48.

20. Compusense Five (2012) Software for sensory analysis Compusense five Release 5.4 with Compusense ${ }^{\circledR}$ FCM $^{\circledR}$. Compusense five Manual version $187 \mathrm{p}$ Compusense Inc. Guelph, Canada.

21. Thompson JL, Drake MA, Lopetcharat K, Yates MD (2004) Preference mapping of commercial chocolate milks. J Food Sci 69: S406-13.

22. Goyal SK, Samsher, Goyal RK (2010) Stevia (Stevia rebaudiana) a bio-sweetener: a review. Int J Food Sci Nutr 61: 1-10.

23. Lisak K, Jelicic I, Tratnik L, Bozanic R (2011) Influence of sweetener stevia on the quality of strawberry flavored fresh yoghurt. Mljekarstvo 61: 220-5.

24. Sumon MH, Mostofa M, Jahan MS, Kayesh MEH, Haque MA (2008) Comparative efficacy of powdered form of Stevia (Stevia rebaudiana Bertoni) leaves and glimepiride in diabetic rats. Bangl J Vet Med 6: 211-5.

25. Weber A, Hekmat S (2013) The effect of stevia rebaudiana on the growth and survival of Lactobacillus rhamnosus GR-1 and sensory properties of probiotic yogurt. J Food Res 2: 136-43. 


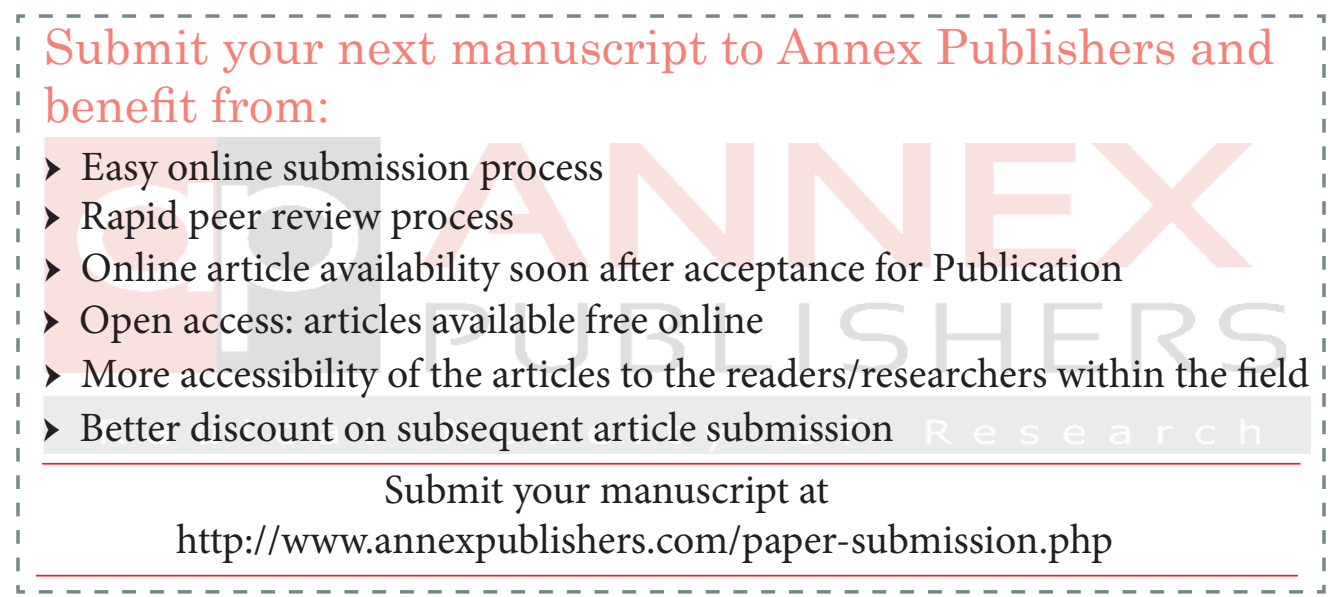

